\title{
Innovation and Product Development through the Creation of Competences in the Metallurgy Industry
}

\author{
Edwin Santamaría-Freire ${ }^{1}$, Leonardo Ballesteros ${ }^{2}$, Klever Moreno $^{3}$, Walter Jimenez ${ }^{4}$
}

\begin{abstract}
The metallurgy industry has been one of the most influential ones in the Province of Tungurahua. However, its weakness lies in the lack of innovation and development of new products; for this reason, it is proposed to learn about the efficiency in the development and innovation of products through the creation of administrative or managing skills. This descriptive research was based on information collected through a survey that was completed by 60 company managers of the industry, which were randomly selected around the province. It let the researches to learn about the competencies of the high and middle management levels of the selected companies by evaluating the strategic areas of the organization such as: finance, sales, production, human resources and managing. The results focused on identify ing competencies in relation to the activities carried out for prototyping and creating new products. It was concluded that communication on sales department is the base for transmitting the needs of customers to the area of production and finance, who use empathy and product orientation to generate alternatives. However, the lack of orientation towards the customer creates difficulties to reflect the products according to the requirements. The area of human resources and administration participated indirectly in the process. From the results, it was concluded that organizations need to generate competencies that allow the innovation and development of products based on the appropriate flow of communication within the process of needs assessment, design and production.
\end{abstract}

Keywords-Innovation, product development, organizational behaviour, skills, business management.

\section{INTRODUCTION}

The development of competencies and managerial skills facilitates the work and functions that we can carry out within an organization since it demands a lot of responsibility, among which are: customer orientation, fulfillment of goals and innovation [1]. In addition, the factors for developing new products in the industry where quality standards and continuous improvement phases must be met require competencies in senior management [2].

The main metalworking industries are located in the provinces of Pichincha, Tungurahua, Guayas, Azuay and Loja.

\footnotetext{
1, 2, 3, 4 Universidad Técnica de Ambato
}

According to figures from the Central Bank of Ecuador, investment in the industrial manufacturing sector has an annual average growth rate of $6.29 \%$ and in the 2014 shows a variation of $11.45 \%$ with respect to 2013 .

Ecuador has an advantage over others in terms of operating costs in the sector; calculations of annual operating costs are based on labor costs. As it is shown in the attached table, the costs of operating in Ecuador are 10\% less than the average annual cost of the competing countries.

\subsection{Product development and innovation}

A paper presented by the United Nations Industrial Development Organization [3] indicates that innovation includes all processes of change and provides solutions applied to everyday problems [4] adds that it is an absolute necessity in companies to survive because if they do not put it into practice they have a great risk of failure. In the same way, Mulet Meliá, [5] points out that any change that generates value, based on knowledge that generates value for the company, is also seen as the result of a complex process.

The design of new products, even the most rudimentary ones, always involves a process of generation of functional morphologies and solutions that may or may not respond to aesthetic issues. [6] The process of creating new products is a difficult and continuous task, since it consists of an activity that should never be isolated because a company must have a vocation of continuity, due to the increasingly short duration of the product life cycle. [7] This process may be a mixture of competencies due to the requirement to coordinate, plan specific activities, which must be followed and properly controlled by the person who is responsible for the product or its interrelation with other departments of the company [2].

The corporate image is the set of specific and personal characteristics of an entity, which create a perceptible and memorable form of itself and differentiate it from other entities. [8] This corporate image is formed by three elements: the logo that is a visual distinctive that represents an entity; The symbol that is a figure or object that has a meaning and constitutes an element of identification; and, the logo-symbol which is a combination of the symbol and the letters [9]. These elements allow to the enterprise to differentiate at first sight from any other company [10].

\subsection{Managerial skills and abilities}

[11] "The effective manager must be able to self-analyze and reflect on himself in an open way, capable of posing and 
sincerely answering questions such as the following: Are my motivations well directed at being a manager? Do I have sufficient skills and abilities for the position? Do I set higher goals for myself? Do I update permanently? (pags. 13 - 15) In addition, [12] "The competences are constituted by three groups of managerial capacities: Technical competences, social skills, conceptual abilities" (pags. 279 - 280) and [13]

Morales [14] was the first who proposed the concept of competition as a characteristic to distinguish workers from performance versus those of high performance. Subsequently, other variants were proposed Vega [15], and Bachenheimer [16], which define competences as a set of knowledge, skills and aptitudes necessary to practice a profession, solve professional problems and work organization [17]

According to Puga [18] "There are two types of skills that must be pointed out: managerial skills, strategies which include those skills necessary to obtain good economic results and are those precise skills to develop and increase their commitment and trust with the company" (page. 77) . To these types of management skills, proper of business must be added skills called personal efficiency. [19]

\section{METHODOLOGY}

The work based on the hermeneutic thought seeks to contrast reality with the theory regarding the generation of competences, generating interpretative knowledge under a qualitative approach that does not presume numerical values in itself, the hypothesis is built after the experience [20]. Hence, it is intended to develop a descriptive research that "works on realities of facts, and its fundamental characteristic is to present a correct interpretation, so that the notes that characterize the reality studied can be obtained," [21].

The study population consists of the formal companies of the body shop industry of the Tungurahua Province, which according to the registration of the Body Shop Chamber is formed in 28 enterprises

The survey is considered as a data collection instrument since it allows to obtain information according to the studied variables and it also keeps the elements around the reality. It is applied through a questionnaire with questions of hierarchical type of 5 levels, validated through experts. It is a valid method considering the study population size and can be divided for different areas analysis such as sales, finance, production, human talent and industry strategy.

The survey was applied to all managers from registered companies, however, only 18 were answered, that means $64 \%$ of the population participated in the research.

The processing of the information is presented through tables and graphs, which starts with the following steps: critical review of the obtained information, repetition of the collection and tabulation or tables according to variables of each hypothesis, which was done in Excel.

\section{RESULTS}

Figure 1 analyses the answers from the sales area questions

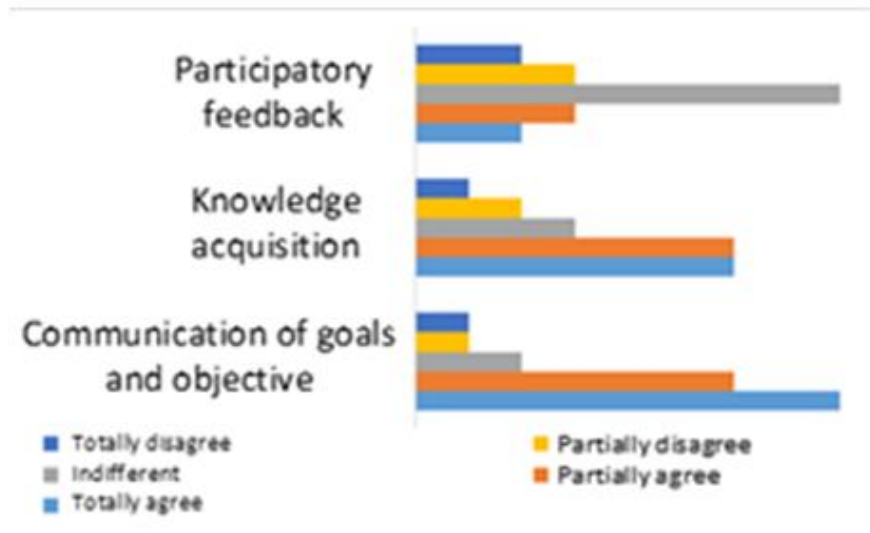

Fig. 1. Elements of the sales area

Figure 2 summarizes the information obtained from the topics related to the area of finance, highlighting the availability of information and the dissemination of results.

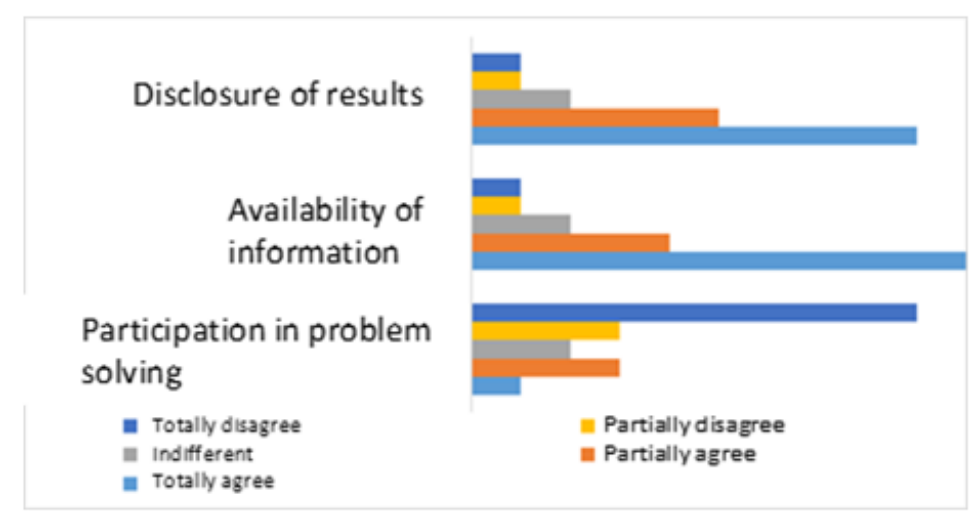

Fig. 2. Elements of the Finance area

Figure 3 shows the content related to the production area.

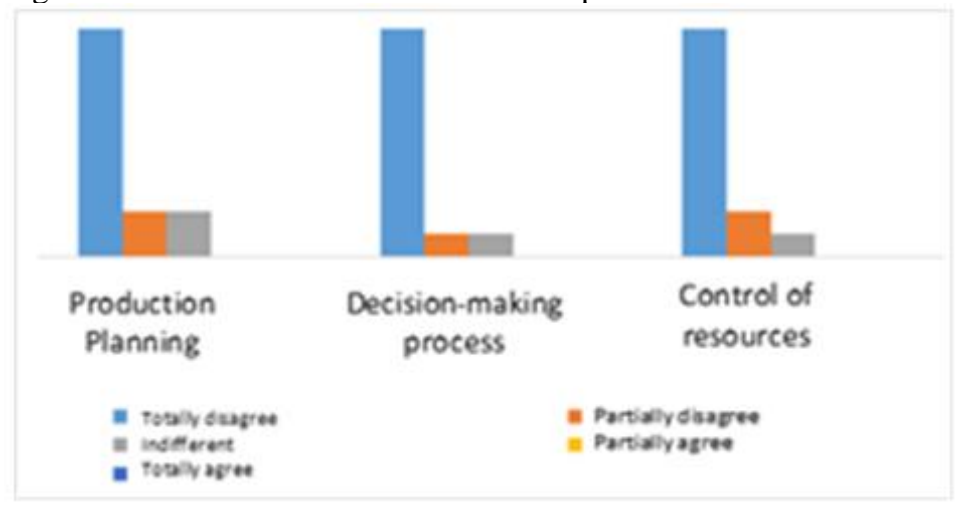

Fig. 3. Elements of Production Area

Figure 4 shows the results of the Human Talent and Administration area 


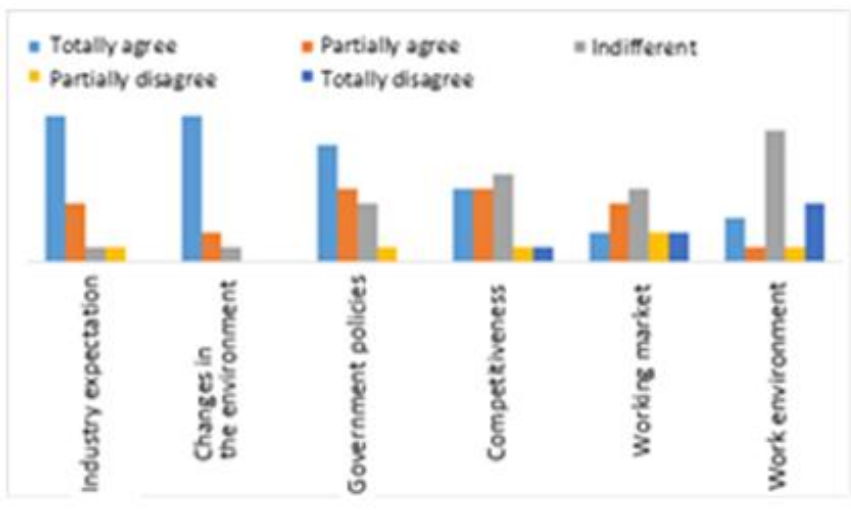

Fig. 4. Expectations of the sector

\section{CONCLUSIONS}

Competencies that allow innovation and product development from the appropriate flow of communication within the process of needs assessment, design and production.

Competencies are considered in the industry as an ability to influence the way to achieve objectives within their staff, achieving the goals of empowerment, product development, commitment to the company and customer orientation. Being these fundamental pillars for the development of products that the customers require.

In the area of Sales, the participation of objectives is a requirement, which generates skills such as empowerment and adherence to goals, which is visible in the generation of results and transmission of customer needs. For this reason, it has within the team the strength to generate new products that the market requires. The metalworking industry has financial information systems that are used for decision making, where other areas are involved for the active participation of the whole company.

The strength of the metalworking industry is the ability to produce and innovate, so they consider that planning is the fundamental pillar for the generation of processes that reduce costs and adapt to new products. On the other hand, within the human resources management, people perform activities since they do not have automated processes; the entrepreneurs seek to prepare themselves with competencies according to the needs of companies.

The expectations for development indicate that they require the systematic analysis of the related economic policies and actors, it is considered appropriate to create policies that promote their development, with innovation being the fundamental pillar for this.

\section{REFERENCES}

[1] Hernández, G. C., \& Valencia, J. C. (2007). Cultural profile of innovative companies. A case study in metalworking companies. Cuadernos de administración.

[2] García, M. (2010). Development of new products. México: Mc Graw Hill

[3] Organización de las Naciones Unidas para el Desarrollo Industrial. (2010). Innovation and creativity in the search for options, feasibility analysis, sources of information. ONUDI.
[4] García, F. U., \& Flores, M. V. (2014). The development of new products in the automotive industry in Tijuana Mexico. La productividad, competitividad y capital humano en las organizaciones, pág. 469.

[5] Mulet Meliá, J. (2014). Innovation, concept and economic importance. Sexth Congreso de Economía de Navarra.

[6] Sierra, M. S. (2005). The process of designing and developing new products and their relationship with Marketing. UNLP.

[7] Pérez, D., \& Pérez Martínez de Ubago, I. (2006). The product. Concept and Development. EOI.

[8] Universidad Simón Bolívar. (2006). Corporate Identity Manual. UASB

[9] Universidad Pontificia Bolivariana. (2011). Corporate identity manual.

[10] Arnau Gifreu Castells. (2016). Corporate image. México: Mc Graw Hill

[11] Asociados, R. M. (2000). Effective Director's Manual. España: Ediciones Gestión S.A.

[12] Moya, J. P. (1997). Strategy management and management skills. Madrid - España: Mater Print.

[13] Belzunce, M. D., Valle, I. D., Martínez, F. J., \& López. (2011). Guide for Emotional Competencies for Managers. España: Anormi S.L.

[14] Morales Muñoz, D. C. (2012). Design of a financial administrative management model for SMEs dedicated to commercial activities in the city of Quito Case study: CERSA CIA. LTDA. Universidad Politécnica Salesiana Ecuador, Ecuador.

[15] Vega Sánchez, D. G. (2008). Strategic Management of the Sales Department Applied in a Commercial Pharmaceutical Company. Universidad Nacional Mayor de San Marcos, Perú.

[16] Bachenheimer, H., \& Valencia, L. G. (2010). Definition of Terms. Business Administration. Corporación Regional d Educación Superior CRES.

[17] Morales Castro, A., Sánchez Rodríguez, B., Morales Castro, J. A., \& Figueroa Flores, J. G. (2005). Finance I. Fondo Editorial FCA.

[18] Puga Muñoz. (2010). Finance and the financial system (Family and Business). Universidad Arturo Prat del Estado de Chile.

[19] Bustos, E. (2003). Administrative process. España: ESIC.

[20] Carrera Hernández, C. (2013). Epistemological foundations of research. Madrid: ESIC.

[21] Sabino, C. (1986). The Paths of Science, an Introduction to the Scientific Method. Madrid: ESIC. 